DOI 10.31558/1815-3070.2020.40.1.14

УДК 81’373.2:821.161.2(038) Стус

\title{
ДОСВІД СТВОРЕННЯ СЛОВНИКА ВЛАСНИХ ІМЕН ПОЕТИЧНИХ ТЕКСТІВ (НА МАТЕРІАЛІ ТВОРЧОСТІ ВАСИЛЯ СТУСА)
}

Розглянуто деякі аспекти онімографії (опис власних імен поетичних текстів). Визначено основні проблеми поетонімології, пов'язані з функціонуванням імені художнього твору, буттям і розвитком імені у складі поетонімосфери і тексту. Запропоновано структуру $i$ зміст словникової статті, щзо передбачають відображення у словнику повної парадигми іменування художнього об'єкта, надання енциклопедичної інформачії, поетонімологічного коментаря, включення необхідного і достатнього контексту поетоніма. Зазначено проблеми і перспективи розвитку поетонімографії.

Ключові слова: власне ім'я, конотонім, контекст, поетонім, протоонім, функція, текст.

Постановка наукової проблеми та її актуальність. На сьогодні в українському мовознавстві існує незначна кількість лексикографічних праць, присвячених повному опису словоформ творів письменника. Найвідомішими фундаментальними роботами є двотомний «Словник мови Шевченка», укладений Інститутом мовознавства імені Олександра Потебні АН УРСР (Київ, 1964), «Словопокажчик драматичних творів Лесі Українки», М. Бойко (1961), «Художнє слово Василя Стефаника» (за ред. І. І. Ковалика, І. Й. Ощипко (1972)), тритомний «Словник мови творів Г. Квітки-Основ’яненка» (1978-1979), «Лексика поетичних творів Івана Франка» (за ред. І. Ковалика, І. Ощипко, Л. Полюги (1990)), «Словник рим С. П. Гребінки» І. Гурина (1992), «Конкордація поетичних творів Т. Шевченка» у 4-х томах (2004) та деякі інші. Не всі зазначені словники уналежнюємо до таких, які побудовано за принципом словників тлумачного типу (пояснення значення слів, граматичні та стилістичні характеристики тощо). Крім того, поза увагою багатьох авторів залишається енциклопедична інформація та коментарі, що виявляють формальний і смисловий зв'язок досліджуваних слів 3 найближчим контекстом. Недостатньо уваги у вітчизняному мовознавстві приділено нагальній проблемі онімографії, тому укладання словника власних імен поетичних текстів Василя Стуса, спрямованого на виявлення зв'язків і відношень поетонімів із контекстом певного твору, що уможливлює цілісну інтерпретацію художнього тексту, вважаємо своєчасним і актуальним.

Аналіз досліджень проблеми онімографії. Функційне навантаження онімів декілька десятиліть є предметом суперечок у лінгвістиці. О. В. Суперанська до мовленнєвих функцій відносить комунікативну (ії різновидами названо ідентифікаційну, адресну, дейктичну, диференційну, описову, звертальну, видільну, перерахувальну), апелятивну й експресивну (Суперанська 276). Л. О. Белей розподіляє антропоніми за стилістичною функцією таким чином: 1) номінативні, 
2) характеризувальні, 3) дейктичні та 4) ідеологічні (подальший розподіл відбувається у межах виокремлених груп) (Белей 24).

Ю. О. Карпенко і М. Р. Мельник виокремлюють шість функцій власних імен у творах Ліни Костенко: 1) номінативну, 2) хронотопічну; 3 ) характеризувальну; 4) виразності, образності, тропеїчності; 5) експресивну; 6) текстоутворювальну. Разом з тим у монографії «Літературна ономастика Ліни Костенко» постульовано поліфункційність поетонімов, що виконують «мало не всі функції відразу» (Карпенко, Мельник). Науковці Донецької ономастичної школи наполягають, що створити ідеальну таксономічну систему функцій поетонімів неможливо через те, що функційні характеристики будуть поповнюватися, а функції поєднуватися. Суттєво, що коли Ю. О. Карпенко і М. Р. Мельник говорять про поліфункційність, вони виявляють функції, які ім'я художнього тексту зреалізовує a priori. Інакше кажучи, характеризувальна, виразності, образності та інші функції навіть не вимагають контекстних доказів. У монографії «Теорія і практика лексикографування поетонімів» В. М. Калінкіна наголошено, що словник власних імен повинен стати поетонімологічним коментарем до функціонування поетонімів у контекстах різного поширення (Калинкин, «Теория и практика»). На жаль, впроваджена науковцем класифікація не має чіткої структури (пор.: зображувально-характеризувальна, іронічна, іронічно-порівняльна, оціннохарактеризувальна, вказівна, локалізувальна, метонімічна і т. ін.), а встановлене функційне навантаження деяких поетонімів не $є$ повним. Беззаперечна цінність лексикографічної праці В. М. Калінкіна полягає в постулюванні ідеї поетоніма як сукупності вживань у тексті: онім (багатофункційна одиниця поетичного мовлення) «3 кожним конкретним вживанням актуалізує лише частину функцій, потенційно властивих йому або зреалізованих у художньому творі» (Калинкин, «От литературной ономастики» 86). Отже, завдання лексикографа полягає не в інтегральному представленні, а в диференціюванні функцій, здійснюваному поетапно: 1) вибрати всі вживання поетоніма в тексті, 2) виділити необхідний і достатній для визначення внеску в образність контекст, 3) встановити функційне навантаження кожного варіанта онімної парадигми.

Мета і завдання дослідження полягають у вдосконаленні онімографічної теорії та практики шляхом укладання «Словника власних імен поетичних текстів Василя Стуса», який вміщує всі (без винятку) онімні одиниці рукописів, білових і чорнових автографів. Основне завдання вбачаємо в вичерпній реєстрації і потрактуванні власних імен в їхніх формальних і семантичних виявах 3 урахуваннях необхідного і достатнього контексту.

Об'єктом дослідження є 668 номінативних одиниць (власних імен, безонімних найменувань, онімно-апелятивних комплексів і відонімних прикметників), вилучених із поетичних творів Василя Стуса. Предмет - функційне навантаження номінацій, встановлюване шляхом з'ясування співпраці досліджуваних одиниць 3 контекстом твору.

Опис фактичного матеріалу та методів, застосованих у процесі аналізу. Матеріалом дослідження стали номінативні одиниці рукописів, білових і чорнових автографів першого тому творів Василя Стуса (книга перша - вірші 1958- 
1970 рр., що увійшли до остаточного варіанту збірок «Круговерть», «Зимові дерева», «Веселий цвинтар»; книга друга - твори періоду 1956-1971 рр., що не ввійшли до трьох перших збірок поета), чотиритомного видання, опублікованого Видавничою спілкою «Просвіта» (Львів, 1994 р.). У роботі застосовано загальнофілологічні прийоми і методи ономастичних досліджень: систематизація контекстів з поетонімами; контекстний аналіз поетонімів; поетонімологічний аналіз; метод реконструювання зв'язків і відношень у парадигмі поетоніма й поетонімосфері; метод інтертекстуального аналізу та ін.

Наукова новизна, теоретична і практична цінність отриманих результатів. Відносно невеликий досвід укладання словників власних імен художніх творів переконує, що створення універсальної моделі словникової статті навіть у мові конкретного письменника навряд чи можливо. Структура і компоненти статті знаходяться у прямій залежності від жанру, літературного напрямку, авторських інтенцій, специфіки твірної бази онімних одиниць, властивостей контексту тощо. Наукова новизна роботи полягає в загальному обгрунтуванні теоретичних основ поетонімографії, зокрема в удосконаленні теорії необхідних і достатніх контекстів поетоніма, розвитку методів та прийомів комплексного аналізу поетоніма - поетонімосфери та ін. Дослідження $є$ певним внеском у сучасну теорію поетонімології за рахунок поглиблення концепції поетонімосфери (розв'язання проблеми зв'язків і відношень між ії компонентами), впровадження ідеї зосередження в імені / частині поетонімосфери / поетонімосфері у цілому образотвірного, сюжетоутворювального, текстотвірного, отже, інтерпретативного потенціалу. Практичну цінність вбачаємо у можливості застосування результатів дослідження в лексикографічній практиці, насамперед в укладанні словників мови письменників як таких, що дають вичерпне уявлення про кожне слово в усіх зафіксованих значеннях, закріплених контекстами творів.

Виклад основного матеріалу й обгрунтування результатів дослідження. Суцільна вибірка номінативних одиниць, зафіксованих у текстах Василя Стуса, дозволяє стверджувати, що у цілісному художньому просторі співіснують поетоніми, різні за розрядами, походженням, змістовим і функційним навантаженням, участю у конструюванні індивідуально-авторської картини світу і т. ін. Переважна більшість імен має вторинне походження і співвідноситься за змістом i формою з історико-культурними (частіше широковідомими) одиницями. Протоіменами проаналізованих творів виступають міфоніми (атланти, Вавілонська вежа, Голгофа, Дажбог, Елізіум), реальні імена історичних діячів (Брєжнєв, Маркс, Микола Щорс, Небаба, Сагайдачний, Самійло Кімка), назви географічних об'єктів (Австралія, Говерла, Гібралтар, Дарниия, Донбас, Єгипет, Запоріжжя, Київ, Крим, Лиса гора, Нагасакі, Почайна), вигадані власні імена на позначення художніх творів і літературних персонажів (Гамлет, Горіо, «Заповіт», Йорик, Лукаш, Мавка, Фавст), реальні імена, що відтворюють коло читання, тих чи тих вподобань автора (Андрій Вознесенський, Бетховен, Блок, Бортнянський, Вишня, Вінграновський, Данте, Модільяні, Сковорода, Чурльоніс), імена, пов'язані з біографією і творчістю Василя Стуса (Валентин Мороз, Вінцас, Са- 
ломея). Крім того, твірною основою багатьох номінативних одиниць стають узуальні або оказіональні конотативні імена (Адам, Африка, дантеси, ловелас, Нагасакі). Для усвідомлення і розмежування твірної бази поетонімів текстів Василя Стуса доцільно ввести т. зв. індекси походження.

Індексом 1 позначено поетоніми, похідні від історико-культурних інтерлінгвальних реальних імен (переважно антропонімів i топонімів): АВСТРАЛІЯ1, АМЕРИКА1, ГАЛІЛЕЙ1, ДАНТЕ1, СГИПЕТ1, КОЗЕРОГ1, МАРКС1, МОДІЛЬЯНІ1, НІЩШЕ1, ОВІДІЙ1, ПЕРСІЯ1, РАФАЕЛЬ1. ІНдекс 2 надано одиницям, похідним від інтралінгвальних реальних імен, які вибудовують історико-культурну і націєтвірну картину світу Василя Стуса (з індексом 2 виступають як загальновідомі власні імена, так і оніми, пов'язані з біографією, колом знайомств поета тощо) : БЕСАРАБКА2, ДОНБАС2, КИїВ2, М. К. ЗЕРОВ2, НКВД2, ОЛЕКСА БУЛИГА2, ПОДІЛЛЯ2, РАХНІВКА2, САГАЙДАЧНИЙ2, СІЧ2, СКОВОРОДА2, СОЛОВЕЦЬКИЙ острів2, СУЛА2, ТАГІЛ2, ХРЕЩАТИК2, ЯРОСЛАВ2. 3 індексом 3 виступають одиниці, похідні від загальновідомих історико-культурних вигаданих імен (переважно міфонімів, заголовків художніх творів або імен літературних персонаЖіВ) : ГАМЛЕТЗ, ГОРІОЗ, ДАЖБОГЗ, ІКАРЗ, «КОБЗАР»З, ЛЮЦИПЕРЗ, МАРКОЗ, ОРМУЗДЗ, ПЕРУНЗ, ПОЛІФЕМЗ, ПРОМЕТЕЙЗ, ХАРОНЗ, ЯРИЛІВ деньЗ.

Твірною основою імен з індексом 4 стали імена в переносному значенні узуальні або оказіональні конотативні оніми. Для відтворення індивідуально-авторської мовної картини світу і встановлення експресивно-образного змісту поетонімів суттєво, що поряд із узуальними конотонімними одиницями на кшталт АФРОДИТА4 'цариця краси', ГОЛГОФА4 'місце страждань, мук, страти', ІУДА4 'зрадник', КРЕЗИ4рl. 'багата людина', РУБІКОН4 'етап, межа, яку треба перетнути', зафіксованих словниками (Лукаш), (Отін), у творах Василя Стуса активно використовуються індивідуальні неологізми, які наповнюють новим змістом широковідомі власні імена або узуальні конотативні одиниці. Так, наприклад, узуальний інтерлінгвальний конотативний топонім КОЛИМА 'місце заслання' (Лукаш 199) набуває нового переносного значення 'пронизливий холод', 'мороз' у контексті Під однією сорочкою Колима $i$ Ташкент (Стус 1(1): 180), перетворюючись на оказіональний конотонім. Пор. також унікальне змістове навантаження поетоніма Робінзон, безпосередньо не пов'язане зі значенням конотативного літературного антропоніма, відомого у ряді мов: 'відлюдник; людина, яка добровільно зважилася на відхід від людей, суспільного життя, пов’язаних з ним стресів' (Отін 320), 'відлюдник, самотня людина' (Лукаш 302). Зіставлення чорнових редакцій вірша «Безсонної ночі» 3 правками: а) Робінзоном. Їй богу. Ліжко. б) Ти ж як палець самотній. Ліжко (Стус 1(1): 231) з остаточним варіантом Емігрантом. Їй-богу. Ліжко. / I на ковдрі-од вікон - грати. / I подушка моя скуйовджена, / і скуйовджена голова (Стус 1(1) : 49) засвідчує реалізацію інтегральної семи імені Робінзон 'емігрант', зумовленої оказіональним значенням відповідного конотоніма, до складу якого входять 'самотність', 'відчуження' тощо. 
Естетичний зміст текстів увиразнюють оказіональні конотоніми, що лежать в основі поетонімів аналізованих збірок. Пор. : АУСТЕРЛІЦ4 'чужий (для України) світ': Коли земля повертається від сония, / ховаючись у тінь капіталістичної сутності тамбережнього материка, / високе небо Аустерліца / чорніє, голубіє, синіє, зеленіє (Стус 1(1): 221); дантеси4pl. 'вбивця': Затихли постріли нацькованих дантесів (Стус 1(2): 88-89); НАГАСАКІ4 'вселюдська трагедія': Наростає грибом над епохою, / Нагасакі й гетто початком (Стус 1(2): 78); IKAPИ4pl. 'безстрашна людина', 'поборник правди', 'пристрастний захисник': Хоч-не-хоч - сійся, / поки в краплях зійдеш, / поки синє / обтече Ікарів крило, / поки видним / стане все, щэо $\epsilon$, щзо було (Стус 1(2): 233); мезозой4 'бездуховність, духовна відсталість', 'застій духовного життя': I хай нова доба гряде - / в ній мезозою темні душі... (Стус 1(1): 80); СВЯТОШИН4 'Батьківщина, своя країна, свій край’: Зазираю в завтра - тьма і тьмуща, / тьма. I тьмуща тьма. I тьмуща тьма. / Тільки чорна водь. I чорна пуща. / А твого Святошина - нема (Стус 1(1): 196); ТУРЕЧЧИНИ4рl. 'культурна відсталість; країни з відсталими поглядами на культуру, поезію тощо’: Тремтіть, Туреччини. Поети не кроти, / але й тоді, як роблять їх кротами, / їм все видніме з моря і землі (Стус 1(2): 88) та ін.

Поетоніми з індексом 5 не мають конкретних протоонімів; основою таких індивідуально-авторських вигаданих імен виступають традиційні для української онімії одиниці на зразок ВАЛЯ5, ВАСИЛЬ5, ГАЛКА5, ГРІША5, ДЕМ'ЯН5, ІВАН5, МАКАР5, ОЛЕКСАНДРА5, СЕКЛЕТА5. До поетонімів 3 індексом 6 уналежнено індивідуально-авторські вигадані імена, похідні від апелятивів (насамперед це заголовки - назви віршів, поем, циклів, збірок): «БІЛЬ БІЛИЙ ДЕНЬ»6, «БОВВАН»6, «ГАЙВОРОНСЬКЕ»6, «ДЕКЛАРАЦІЯ ПОЕТА І ГРОМАДЯНИНА»6, ЗАВЗЯТТЯ6, ЗИМА6, «ОПТИМІСТИЧНЕ»6, «РОЖЕВЕ ПІВКОЛО»6. Індексом 7 позначені безіменні номінації, які приховують (не називають) ім'я Бога, Батьківщини та деякі інші (БОГ7, ГОСПОДЬ7, ВІТЧИЗНА7) або набувають символьного значення у цілісному контексті поезії (ніхто7, Ніщо7, ТИ7). Пор. : Я був у натовпі. Я був н $\boldsymbol{i}$ к и м. / Я сором відчував за власну ницість, / за воєнрабство (Стус 1(1): 184); О мить блаженства - $і$ людей $і$ псів. / Одні щасливі ницістю своєю / $і$ приналежністю чотириногим / так низько хиляться благочестиво / перед Нічим, що дивиться зокіл (Стус 1(1): 184); А чи любив? Мабуть, любив, бо знав, / щзо в изілім світі тільки Ти і Вічність (Стус 1(2): 56).

До словника вміщено словосполучення з відонімними (переважно відміфонімними) прикметниками, що усвідомлюються як найбільш виразний засіб створення образності тексту: Кожного із нас / долає і підносить. / Та бійся знесеному буть: / Ікарове окрилля / вік навертатиме на путь / досадного знесилля (Стус 1(2): 173), Світ перейду - i упаду / десь на чужій стерні, / немов заброда. Перейду / життям - по стороні. / 3 крихкого краю. По ребру / Адамовім. І знов / ітиму - казематним сном, / не зрадивши добру (Стус 1(2): 104), а також онімні перифрази, за допомогою яких вибудовується метафоричний контекст твору: $I$ радісним буремним громом / спадають з неба блискавиці, / Tарасові провісні 
птиці-/ слова шугають над Дніпром (Стус 1(1): 91).

Загальноприйнятим у поетонімології $є$ твердження про те, що поетонім $\epsilon$ «сукупністю вживань» імені в тексті (Калинкин, «От литературной ономастики» 87). Повний набір (сукупність) онімних і безонімних номінацій, співвіднесених з одним художнім об'єктом (денотатом), позначаємо як парадигму, оскільки всі номінації існують в єдності (цілісності) - поетонімі, який займає певне місце в ядерній - периферійній зоні поетонімосфери, відповідній підсистемі і т.д. (Кравченко, «Поетика зв'язків» 36). Всі варіанти іменування художнього об'єкта (контекстні синоніми, художні дескрипції, перифрази тощо) спрацьовують на з'ясування текстотвірної ролі поетоніма і забезпечують розширення образотвірного потенціалу номінативної одиниці. Двокомпонентні парадигми поетонімів вживаються найчастіше у контекстах порівняння / ототожнення, наслідком яких стає актуалізація оцінювально- або зображувально-характеризувальної функції: Петро вертався з клубу, / зальотник визнаний, ганяв ичигарку / кутками свого всміхненого рота, / виспівував Марину, наче гімн (Стус 1(2): 174); А скажи - Модільяні був idiom? - / допитувалась вона, / коли я вправними, як у піаніста, пальиями / вигравав на засмаглих персах (Стус 1(1): 60); Украӥно моя! Украӥно. Ти слухана казка, / Недослухана казка, сповита у зустрічний дим (Стус 1(2): 205); Як удова, з оклунком / заходить Украӥна в рідний дім: / напитися, спитати про здоров'я / i сісти скраю лавки (Стус 1(2): 156). Непоодинокими у досліджуваних збірках поезій $є$ багатокомпонентні (розширені) парадигми поетонімів на кшталт БЕТХОВЕН1 / ноктюрн / шалений бог / АРХІЛОХ1 / епілептик / маестро (Стус 1(2): 68-69), МАНЕВИЧ2 / сврей / невір / маячний і мудрий сніг (Стус 1(1): 205), СТАЛІН2 / не бог / сонця син / тиран / земний і божий суддя (Стус 1(2): 265), СТАЛІН2 / геній / ховрашок (пор. : Коли б Сталіну / ббрили завчасно вуса, / геній скидався б / на ховрашка (Стус 1(2): 184)). Тимчасове зупинення руху поетоніма в тексті означає встановлення функційного навантаження кожного варіанта онімної парадигми в кожному “окремо взятому” контексті.

Наступний крок у напрямку занурення в поетику тексту, що зароджується 3 розкриттям (розвитком) поетоніма, потребує вирішення питання «необхідного і достатнього» контексту, який дозволив би з'ясувати вклад поетоніма в образність твору. У поодиноких випадках виявилося доцільним виокремлення мінімального контексту (слово або словосполучення): іграшковий Микола Щорс, товаришу Хароне, ода рідній КПРС, гетери Антарктиди та ін., який спрацьовує на реалізацію тієї чи тієї функції, закріплюючи текстотвірну роль поетоніма. Факультативний характер носить позначення семантичних типів контекстів: метафоричний контекст: Навкруг землі мої кружляли мрії, / $і$ в серие хлюпав хвилями Дніпро (Стус 1(1): 141), контекст-медитація: О Боже праведний, важка докука - / сліпорожденним розумом збагнуть: / ти в иьому світі - лиш кавалок муки, / отерплий і розріджений, мов ртуть (Стус 1(1): 62), контекст кола читання або вподобань ліричного героя: < .. > читаючи, люблю / твойх Орхана, Незвала $і$ Данте, / в дев'яте коло прагнучи стремлю (Стус 1(1): 94), контекст-актуалізатор заголовка: Ніч протовпиться, як n'яниия, / по кімнаті, по стінах шастає; Другу ніч уже, другу - не спиться («Безсонної ночі») та ін. 
Перспективною проблемою поетики онімів є з'ясування звукоподібності ім'я - контекст (залізнобетонний Донбас, скараний Якір тощо), закріплення зв'язку звучання - значення, зактуалізоване за допомогою онімної рими. Словник власних імен поетичних текстів Василя Стуса може прислужитися тим, хто досліджує проблему розмежування рим за ступенем оригінальності. У проаналізованих поезіях впливовість поетоніма і взаємодія онім - текст посилюється за рахунок римокомпонентів Гібралтар - кар («За що ти судиш цілий світ...»), зозулі - Засулля («Лубенські пам’ятаєш зозулі?»), Цінандалі - генацвале («Грузинському другові»), амфори - Африки («Зимові дерева»), Карарри - кари («Не заворожиш світ очима...»), Кисегачу - трачусь («Утік з казарми, прослав шинельку відкинув ратиці...»), Одесі - дантесів («Ти бачиш - попід часом, попід віком...») та багато інших. Визначення точної і неточної онімної рими у словнику супроводжується встановленням звучності (звукової потужності) римопари 3 онімом. Наприклад, онімна суміжна рима аж⿻ до хмар - Волосожсар має низьку звукову потужність, підсилену алітерацією дзвінкого ж⿻ (Кравченко, «Словник власних імен» 60); неточна суміжна рима Кисегачу - трачусь має середню потужність (Кравченко, «Словник власних імен» 122) тощо. Для повноцінного аналізу індивідуального стилю автора треба виявити репертуар рим комплексного (цілісного) тексту, розмежовуючи: 1) унікальні (одиничні, що утворюють одну римопару), 2) орихінальні (поширені в двох-трьох текстах), 3) типові (поширені в чотирьох текстах), 4) банальні / шаблонні (поширені в багатьох текстах).

Функційне навантаження поетонімов встановлюється відповідно до традиції Донецької ономастичної школи, тобто з усвідомленням функції власного імені художнього тексту як специфічної діяльності, спрямованої на створення художньої образності; «змінної», що трансформується разом із граматичною формою, варіантами поетоніма, семантичними і синтаксичними властивостями контексту, в який «занурений» поетонім, інформаційним і естетичним висловлюванням в цілому. Серед образотвірних і текстоутворювальних функцій поетонімів актуалізовані такі: алюзійна, вказівна, генетивна, зображувальна, зображувально-оцінювальна, зображувально-характеризувальна, іронічна, локалізувальна, метафорична, метонімічна, мнемонічна, оцінювальна, порівняльна, риторичне звертання, риторичне питання, саркастична, символічна, характеризувальна, хронотопічна та ін. Приклади, наведені у словнику, підтверджують, що зрідка поетонім виконує лише одну функцію (звичайно, не йдеться про поетичну і текстотвірну функції, які $є$ апріорними для всіх власних імен художнього тексту). Так, у контексті Крутоберега в'юниться Борзна, / і образ твій лежсить в їі nотіччі (Стус 1(2): 56) зактуалізовано зображувально-характеризувальну функцію гідропоетоніма Борзна; контекст 3 вітчизни, з вір сам Бог судив / тобі на Африку, на шлях, / $і$ Гібралтар тебе ковтав, / а ти підводив горло вгору (Стус 1(2): 72) засвідчує локалізувальну (переміщення у просторі) роль топопоетоніма Африка і т.ін.

Змістова значущість і плідна співпраця імені з контекстом виявляється суміщенням двох - чотирьох функцій, які посилюють образотвірну та / або тексто- 
твірну роль онімної одиниці. Наприклад, антропоетонім АБРАМ4 виконує вказівну й оцінювально-характеризувальну функції у контексті На привалі - Цінандалі, / і на тактиці - як сван, / порятуєш, генацвале, / чи Абрам, ачи Іван (Стус 1(2): 108); історико-культурний антропоетонім АНДРІЙ ВОЗНЕСЕНСЬКИЙ2 у контексті Я вчора дістала збірку / Андрія Вознесенського, / читала і перечитувала / "Осінь у Сігулді», / $і$ думала: для розлуки / осені не чекають (Стус 1(1): 66) вживається в генетивній та опосередковано характеризувальній функції; порівняльну і метафоричну функції зактуалізовано в контексті біблійного поетоніма АПОКАЛІПСИСЗ: Зголоднілий вершник / сидить на гулкому сериі, але вгризти / його не може. Натерпіле серие / розбухає, як квітка Апокаліпсису (Стус 1(2): 57); метонімічну і зображувально-характеризувальну функції БЛОК2 у контексті Хрещатиком вечірнім під неоновим / блідавим світлом, у суху поземку / ти плинеш, таємнича незнайомко / із Блока - в вечір, ніби в синій сон (Стус 1(1): 114) і т. ін.

Поетику зв'язків і відношень імені - тексту нарощують поетоніми, які виконують три або чотири функції одразу. Пор. : Ми сиділи за пляшкою шампанського / в тихенькому прокуреному кафе, / $і$ вона відчувала себе царицею, / Афродитою, щзо проминувши рибалок / (за столиками забивали козла), / алкоголіків, невтомних шукачів / великих жіночих бюстів, / щойно зайшла в таверну <...> (Стус 1(1): 191) (характеризувальна, алюзійна, пародійна функції); Їх було двоє прибиральниия і двірник / Вони сиділи на Володимирській гіриі $-/<\ldots>$ / i жваво обговорювали замацану статтю / "Як ми готуємо пленум райкому" / але прибиральниия не здавалась: / по пам'яті вона иитувала Брєжнєва (Стус 1(1): 157) (вказівна, метонімічна, оцінювально-характеризувальна функції); Я вигукував 3 усіма “гірко" / і думав про Валентина Мороза, / згадував його лоб і волосся й очі / і переконувався знову й знову, / що горішньою частиною обличчя / він скидається на пророка (Стус 1(1): 180) (зображувально-характеризувальна, порівняльна, мнемонічна функції); Пригадалися роси ранні, / пісня Романова, / і тінями Елізіуму / стали спогади, як ножі < .. > (Стус 1(1): 66) (порівняльна, метафорична, зображувально-характеризувальна, мнемонічна функціі).

Структура і компоненти словникової статті поодинокого власного імені, вжитого у поетичному тексті, мають такий вигляд:

1. Заголовне слово у всій сукупності варіантів (парадигма поетоніма).

2. Статистична інформація (кількість вживань).

3. «Адреса» ілюстративних прикладів (дані про рік написання, видання та ін.).

4. Енциклопедична або лінгвістична інформація для похідних власних імен.

5. Ілюстративні приклади (контексти з поетонімом та / або мінімальні контексти).

6. Ономапоетичний коментар (якщо поетонім налаштований на іронічне, пародійне або інше обігравання тексту-джерела).

7. Перелік функцій.

Пор.: ВІНГРАНОВСЬКИЙ2 (1) - поодинокий історико-культурний антропоетонім у вірші «Самота самоти» (березень 1965 р.; зб. «Зимові дерева»). 
[Протоонім Микола Степанович Вінграновський (1936-2004) - український письменник-шістдесятник, режисер, актор, сценарист та поет].

К. : Це нічого, щзо хворість? / Це нічого, щзо прорість / росте непомітно, як гріх? / Снігу! Мов же! / (казав Вінграновський - ословся!) / Самота самоти. I Вузол тиші (Стус 1(1): 120).

Ф.: мнемонічна, характеризувальна (Кравченко, «Словник власних імен» 52).

ГОРІО3 (1) - поодинокий історико-культурний антропоетонім у частині «Годинник!...» циклу «Рінь» (без дати), не включеного автором до поетичних збірок (Стус 1(2): 277).

[Протоонім Горіо - ім'я центрального персонажа роману французького письменника Оноре де Бальзака «Батько Горіо» (1832), що згодом увійшов до зібрання творів «Людська комедія»].

К. : Годинник! / Моя пекельна машинко! / Ти так страшно мовчиш! / Ти небезпечно слухняний! / I коли мені радісно, / ти як старий Горіо / візит наносиш! (Стус 1(2): 187).

Ф. : порівняльна, метафорична (Кравченко, “Словник власних імен” 70-71).

НІЦШЕ1 (1) - поодинокий історико-культурний антропоетонім у вірші «Три скелети сидять за кавою...» (1970).

[Протоонім Фрідріх Вільгельм Ніцше (1844-1900) - відомий німецький філософ, психолог і класичний філолог, представник ірраціоналізму].

К. : Три скелети сидять за кавою / і провадять про філософію Ніщше, / до них підсідає рудава бестія / $і$ починає з одного кпити, / що той недоладно грає справжню / людину (Стус 1(2): 144). Визначення справжня людина спрямоване на пародійне обігравання образу надлюдини Ф. Ніцше.

Ф.: генетивна, опосередковано характеризувальна, іронічна (Кравченко, «Словник власних імен» 164).

Якщо у поетичному тексті вживається декілька поетонімів, доцільно встановлювати зв'язки і відношення досліджуваної номінативної одиниці з іншими власними іменами тексту. Інноваційним складником словникової статті стало виявлення всіх онімних (безонімних) найменувань цілісного тексту, угрупування ïх у поетонімосферу та / або виділення мікросистем поетонімосфери. Виокремлення мікросистем дозволяє витлумачувати змістовно-концептуальну інформацію тексту. Так, наприклад, відконотонімні топопоетоніми КОЛИМА ТАШКЕНТ вступають у відношення протиставлення завдяки актуалізації оказіональної семи 'пронизливий холод’ і узуальної семи 'нестерпна спека', завдяки чому імена виконують метафоричну і характеризувальну функцію: Чоловік $n i$ дійшов до меморіуму / і прочитав на ньому власне ім'я: / вічна слава героям, / що полягли за незалежність Вітчизни. / Йому приємно й боляче. / Під однією сорочкою Колима і Ташкент (Стус 1(1): 180). У поезії «Ця п’єса почалася вже давно...» поетонімосфера з онімом-домінантою ЩАСЛИВИЙ ЙОРИК вміщує мікросистему ЙОРИК - ніхто, побудовану на протиставних відношеннях: Нині Йорик, / а завтра вже ніхто. Чекай на роль, / якою і почнеш найменуватись, / 
допоки скопу. Раз єдиний-Йорик, / а все життя-ніхто. Ні тобі виду, / ні імені. А грай чуже занудне / наміптане життя - самі повтори (Стус 1(1): 169).

Між компонентами поетонімосфери МАРКО (БЕЗСМЕРТНИЙ) - ВОЛОДИМИР ІЛЛІЧ ЛЕНІН («Марко Безсмертний») встановЛюється унікальний смисловий зв' язок, який передбачає відношення протиріччя: Напередодні всенародного свята, / покинувши могилу, / Марко виграбався на світ < .. > Тепер можна й відзначити / десятлітній ювілей своєї смерті. / I Марко, махнувши рукою, / вирішив проциндрити / частину заощаджених за десять років / партійних внесків < ..> - Світ відзначав 100-літній ювілей / Володимира Ілліча Леніна (Стус 1(1): 189).

Відношення перетину, що мають опертям змістовий збіг, дозволяють угрупувати в окрему мікросистему імена ЗЕРОВ, ВИШНЯ, СКОВОРОДА («Лубенські пам'ятаєш зозулі? Здасться, з-перед світу гомоніли...»), оскільки всі письменники походять з Полтавщини: <...> A там, де / дума, в золотій соломі, пригашеній сутемрявою, яйия / заблуклої казкової несучки. Зеров і Вишня, $\boldsymbol{i}$ Сковоpoда (Стус 1(2): 161). Пор. складники поетонімосфери: мікросистема 1) ЗЕРОВ - ВИШНЯ - СКОВОРОДА; мікросистема 2) СУЛА - ЗАСУЛЛЯ. Перетин між іменами ХРЕЩАТИК - БЛОК - незнайомка («Хрещатиком вечірнім під неоновим...») засвідчує створення іронічного змісту, осмислюваного 3 урахуванням найширшого культурного контексту: Хрещатиком вечірнім під неоновим / блідавим світлом, у суху поземку / ти плинеш, таємнича незнайомко / із Блока - в вечір, ніби в синій сон (Стус 1(1): 114).

Відношення включення зреалізовані у мікросистемах поетонімів, що мають інтегральні семи на кшталт 'автор - назва твору': «СИМФОНІЯ ВЕСНИ» МАНЕВИЧ, АНДРІЙ ВОЗНЕСЕНСЬКИЙ - «ОСІНЬ У СІГУЛДІ» ТОЩО. Змістова еквівалентність (сема 'місце заслання') успільнює компоненти мікросистеми соловки - сибіри - магадани: О краю мій, коли тобі проститься / крик передсмертний $і$ важка сльоза / розстріляних, замучених, забитих / по соловках, сибірах, магаданах? (Стус 1(2): 46) і т. ін.

Висновки та перспективи дослідження. Дослідження власних імен як значущих складників поетичного мовлення спрацьовує на цілісне уявлення про мовну особистість і динамічну мовну картину світу Василя Стуса, що дозволяє більш свідомо потрактовувати націєтвірний потенціал Стусівського тексту. Висвітлення імені крізь призму тексту дозволить усвідомити ідейно-ціннісний зміст певного твору і цілісної творчості поета. Вочевидь, створити ідеальну систему функцій поетонімів неможливо, але укладання словників власних імен українських поетів і письменників сприяє вдосконаленню класифікації поетичних функцій онімів, прийомів уніфікації поетонімологічного коментаря, засобів потрактування контекстної семантики власних імен, оскільки художній пошук є принципово нескінченним. 


\section{Література}

1. Белей Л. О. Нова українська літературно-художня антропонімія : проблеми теорії та історії (монографія). Ужгород, 2002. $176 \mathrm{c.}$

2. Калинкин В. М. От литературной ономастики к поэтонимологии. Ономастичні науки. 2006. №1. C. 81-89.

3. Калинкин В. М. Теория и практика лексикографии поэтонимов (на материале творчества А. С. Пушкина). Донецк : Юго-Восток, 1999. 247 с.

4. Карпенко Ю. О., Мельник М. Р. Літературна ономастика Ліни Костенко. Одеса : Астропрінт, 2004. 215 с.

5. Кравченко Е.О. Поетика зв’язків і відношень імені - тексту - поетонімосфери: дис. ... д.філол.н. : 10.02.15. К. : Київський національний університет імені Т. Шевченка, 2017. $560 \mathrm{c.}$

6. Кравченко Е.О. Словник власних імен поетичних текстів Василя Стуса. Т. 1. Вінниця: ДонНУ імені Василя Стуса, 2020. 288 с.

7. Лукаш Г. П. Словник конотативних власних назв. Вінниця : ТОВ «Нілан-ЛТД», 2015. $392 \mathrm{c}$.

8. Отин Е. С. Словарь коннотативных собственных имен. М. : ООО «А Темп», 2006. 440 с.

9. Суперанская А. В. Общая теория имени собственного. М. : Наука, 1973. 366 с.

\section{Список джерел ілюстративного матеріалу}

1. Стус В. С. Твори. Т. 1. Кн. 1 : Зимові дерева. Веселий цвинтар. Круговерть. Л. : ВС «Просвіта», 1994. $431 \mathrm{c.}$

2. Стус В. С. Твори. Т. 1. Кн. 2 : Поетичні твори, що не ввійшли до збірок (1958-1971). Л. : ВС «Просвіта», 1994. 302 с.

\section{References}

1. Beley, Lyubomir. Nova ukrayinska literaturno-khudozhnya onymiya: problem teorii ta istorii (monohrafiya). Uzhgorod, 2002. Print.

2. Kalinkin, Valeriy. "Ot literaturnoy onomastyki k poetonymolohii" (From literary onomastics to poetonymology). Onomastychni nauki 1 (Onomastic sciences 1), 2006. 81-89. Print.

3. Kalinkin, Valeriy. Teoriya i praktika leksikohrafii poetonymov (na materiale tvorchestva A. S. Pushkina). Donetsk : Yugo-Vostok, 1999. Print.

4. Karpenko, Juriy, and Miroslava Mel'nyk. Literaturna onomastyka Liny Kostenko. Odesa : Astroprint, 2004. Print.

5. Kravchenko, Ella. Poetyka zvyazkiv i vidnoshen' imeni - tekstu - poetonimosfery. Diss. U of Kuiivs'kyy natsional'nyy universytet imeni Tarasa Shevchenka, 2017. Print.

6. Kravchenko, Ella. Slovnyk imen poetychnykh tekstiv Vasylya Stusa 1. Vinnytsya: DonNU imeni Vasylya Stusa, 2020. Print.

7. Lukash, Halina. Slovnyk konotatyvnykh vlasnykh nazv. Vinnytsya : TOV «Nilan-LTD», 2015. Print.

8. Otin, Evgeniy. Slovar' konotatyvnykh sobstvenykh im'on. Moskva: OOO «A Temp», 2006. Print.

9. Superanskaya, Aleksandra. Obshchaya teoriya imeni sobstvenoho. Moskva: Nauka, 1973. Print.

\section{List of Sources}

1. Stus, Vasyl'. Tvory 1. Kn. 1: Zymovy dereva. Veselyy tzvyntar. Kruhovert'. L'viv: «Prosvita», 1994. Print.

2. Stus, Vasyl'. Tvory 1. Kn. 2: Poetychny tvory, shcho ne vviishly do zbirok (1958-1971). L'viv: «Prosvita», 1994. Print. 


\section{THE EXPERIENCE OF CREATING A DICTIONARY OF PROPER NAMES FROM POETIC TEXTS (BASED ON THE WORKS BY VASYL'STUS) \\ Ella Kravchenko}

Department of General and Applied Linguistics and Slavonic Philology, Vasyl' Stus Donetsk National University, Vinnytsia, Ukraine

\section{Abstract}

Background: The most important problem of lexicography remains the creation of dictionaries of onym vocabulary as an essential addition to the dictionary of the writer's language. The structure of an article with a poetonym, the explication of connections and relations of the onym unit presented in the dictionary with other proper names of the studied text, the participation of a poetonym in the creation of the text imagery requires a comprehensive discussion.

Purpose: The purpose of the analysis is to improve the theory and practice of onymography by creating the dictionary of proper names from poetic texts by Vasyl' Stus, which contains all nominative units of his manuscripts, fair copies and draft.

Results: The proposed structure of the dictionary contains the following components: a complete naming paradigm for the poetic object, the encyclopedic information, the onomapoetic commentary, and a necessary and sufficient context. An innovative component of an article with a poetonym is the microsystems of the poetonymosphere.

Discussion: The study of proper names as significant components of poetic speech contributes to a holistic idea of the linguistic personality and the dynamic linguistic picture of the writer's world. The presentation of onyms in dictionaries allows one to evaluate the ideological and artistic content of a particular work as well as determine its role in the complete corpus of the author's texts. The compilation of such dictionaries contributes to the improvement of the classification of poetic functions of onyms, the methods of unifying the onomapoetic commentary, the explication of ways of interpreting the contextual semantics of names, etc.

Keywords: proper name, connotonym, context, poetonym, protoonym, function, text.

Vitae

Ella Kravchenko is a Doctor of Philology, Associate Professor of Department of General and Applied Linguistics and Slavonic Philology at Vasyl' Stus Donetsk National University. Her areas of research interests include literary onomastics, poetonymology and poetonymography, lexicology, linguistic poetics, text linguistics, intertextuality.

Correspondence: ella.krav4enko@gmail.com

Надійшла до редакції 28 липня 2020 року Рекомендована до друку 15 вересня 2020 року 